University for Business and Technology in Kosovo

UBT Knowledge Center

Nov 2nd, 9:00 AM - Nov 3rd, 5:00 PM

\title{
Internet Banking and Technology acceptance Model (TAM): is it applicable to users and non users: An empirical study of Banks in Albania
}

Zhanina Dapi

University of Tirana, dapi.zhanina@gmail.com

Follow this and additional works at: https://knowledgecenter.ubt-uni.net/conference

Part of the Business Commons

\section{Recommended Citation}

Dapi, Zhanina, "Internet Banking and Technology acceptance Model (TAM): is it applicable to users and non users: An empirical study of Banks in Albania" (2012). UBT International Conference. 52.

https://knowledgecenter.ubt-uni.net/conference/2012/all-events/52

This Event is brought to you for free and open access by the Publication and Journals at UBT Knowledge Center. It has been accepted for inclusion in UBT International Conference by an authorized administrator of UBT Knowledge Center. For more information, please contact knowledge.center@ubt-uni.net. 


\title{
Internet Banking and Technology acceptance Model (TAM): is it applicable to users and non users: An empirical study of Banks in Albania.
}

\author{
Zhanina Dapi, MSc, \\ Faculty of Economy \\ University of Tirana \\ dapi.zhanina@gmail.com
}

\begin{abstract}
Traditional branch-based retail banking remains the most widespread method for conducting banking transactions in Albania as well as any other country. However, Internet technology is rapidly changing the way personal financial services are being designed and delivered. The explosion of Internet usage and the huge funding initiatives in electronic banking have drawn the attention of researchers towards Internet banking. In the past, the conventional focus of Internet banking research has been on technological development, but this is now shifting to user-focused research. Although millions of (Lek) have been spent on building Internet banking systems, reports have shown that potential users may not use the systems in spite of their availability. This point outs the need for research to identify the factors that determine acceptance of Internet banking by the users. The primary objective of this research is to extend the technology acceptance model (TAM) in the context of Internet banking. This research also identifies critical individual difference variables (i.e. computer self-efficacy) that have a significant effect, through the TAM framework, on the intention of potential users to use Internet banking. By explaining usage intention from the user's perspective, the findings of this research will not only help Internet banking authorities to develop better user-accepted Internet banking systems, but also provide insights into how to present the new IT to potential users. The findings of this study strongly support the appropriateness of using TAM to understand the intention of people to adopt Internet banking services. Significant effects of perceived usefulness, perceived ease of use, and perceived credibility on behavioral intention were observed, with perceived ease of use exerting a stronger influence than both perceived usefulness and perceived credibility. In addition, the Internet banking authorities need to concern themselves less with directly influencing behavioral intentions. These internal psychological processes will result if the belief formation is appropriately managed. Thus, management attention might be more fruitfully focused on the "development" of belief. Especially, the Internet banking authorities should employ training and promotion approaches to develop the customers' beliefs of usefulness, ease of use, and credibility in the system, which in turn will influence the behavioral intention to adopt Internet banking services.

Our results provide evidence of the significant effects of the individual difference variable (i.e. computer self-efficacy) on behavioral intention through perceived ease of use, perceived usefulness, and perceived credibility.
\end{abstract}

Keywords: Virtual banking, Individual perception, Data security, internet banking service. 